\title{
Is God a Preferred Creditor? Tithing as an Avoidable Transfer in Chapter 7 Bankruptcies
}

\author{
Steven Hopkins $\dagger$
}

Tithing is the ancient practice of giving one-tenth of one's annual income to a church. ${ }^{1}$ It dates at least to the Book of Genesis, when Abraham paid tithing to Melchizedek. ${ }^{2}$ To many Christians, tithing is "a debt which everyone owes to the Lord for his use of the things that the Lord has made and given to him to use." ${ }^{3}$ So important is the payment of this debt that "the Lord, to whom one owes tithing, is in a position of a preferred creditor. If there is not enough to pay all the creditors, he should be paid first."

Fraudulent conveyance law, though not as ancient in origin, has also been around for a long time. In 1571, Parliament passed a statute making illegal and void any transfer made for the purpose of delaying, hindering, or defrauding creditors. ${ }^{5}$ This prohibition has survived for over four hundred years and is found today in $\S 548$ of the Bankruptcy Code. ${ }^{6}$ Section 548 allows the trustee of a debtor's estate to void not only transfers made with

$\dagger$ B.A. 1990, University of Utah; M.B.A. 1995, The University of Chicago; J.D. 1995, The University of Chicago.

1 The American Heritage Dictionary of the English Language 1181 (Houghton Mifflin, 3d ed 1992).

2 See Genesis 14:20. The most widely cited scriptural reference to the commandment and blessings of tithing is found in the Book of Malachi:

Will a man rob god? Yet ye have robbed me. But ye say, Wherein have we robbed thee? in tithes and offerings. Ye are cursed with a curse: for ye have robbed me, even this whole nation. Bring ye all the tithes into the storehouse, that there may be meat in mine house, and prove me now herewith, saith the Lord of hosts, if I will not open you the windows of heaven, and pour you out a blessing, that there shall not be room enough to receive it.

Malachi 3:8-10 (emphasis omitted).

3 In re Packham, 126 Bankr 603, 608 n 8 (Bankr D Utah 1991), quoting Elder Marion G. Romney, Address at Brigham Young University (Nov 5, 1968), reprinted in Speeches of the Year, The Blessings of an Honest Tithe 4 (Brigham Young, 1968).

4 Id.

- Douglas G. Baird and Thomas H. Jackson, Cases, Problems, and Materials on Bankruptcy 357 (Little, Brown, 2d ed 1990).

6 Bankruptcy Reform Act of 1978, 11 USC $\S 548$ (1988). 
the intent to defraud or delay creditors, but also all transfers for which the debtor voluntarily or involuntarily "received less than a reasonably equivalent value" if the debtor was insolvent when the transfer was made or became insolvent as a result of the transfer. ${ }^{7}$ This means that gifts and charitable contributions, which by definition are not exchanged for a reasonably equivalent value, are avoidable under $\S 548$ even when given in good faith. ${ }^{8}$ This rule protects creditors from crafty debtors who might attempt to keep their assets by, for example, making arrangements to give them to friends for a while, and from naive debtors who, in spite of their mounting financial obligations, might sell assets for far less than they are worth or give them to charitable organizations.

These ancient laws of tithing and fraudulent conveyance rarely conflict, but when they do, both God and creditors can assert valid claims. Clearly, the debtor should have paid them both. This Comment examines what happens when the Law of God and the law of bankruptcy meet head on. In such instances, statements by the church that the Lord should be a preferred creditor do not "make the Lord a priority creditor in bankruptcy." However, the Constitution and the Religious Freedom Restoration Act of 1993 ("RFRA") 10 are in a position to protect tithing paid without fraudulent intent, and their approach to tithing and fraudulent conveyance law in Chapter 7 bankruptcies holds important implications for the continued vitality of tithing as a religious exercise.

This Comment examines whether tithing and other religiously required contributions should be treated as fraudulent conveyances in Chapter 7 bankruptcies. Section I explores the difficulties courts face when they try to balance sincere religious beliefs against the legitimate interests of creditors in Chapter 7 bankruptcy proceedings. Section II examines the impact of RFRA on the ability of courts to classify tithing as a fraudulent conveyance under $\S 548$ and concludes that RFRA's compelling interest and least restrictive means requirements provide clear grounds for disallowing creditor avoidance of sincere tithing payments.

Id.

8 See Hernandez $v$ Commissioner of Internal Revenue, 490 US 680, 690 (1989), reh'g denied, 492 US 933 (1989) (denying tax deduction for payments to church "in exchange" for "auditing" and training services). See also 26 USCA $§ 170$ (West Supp 1995) (defining charitable contributions for tax purposes).

s Packham, 126 Bankr at 608 n 8.

10 Pub L No 103-141, 107 Stat 1488 (1993), codified at 42 USC § 2000bb (Supp 1993). 


\section{Tithing, the Constitution, AND Fraudulent CONVEYANCE LAW}

Before RFRA, courts had two principal means of protecting tithing from creditors. The first was finding that the tithing was "exchanged for" a "reasonably equivalent value," as the Bankruptcy Code requires. The second was applying the First Amendment, which provides that "Congress shall make no law respecting an establishment of religion, or prohibiting the free exercise thereof...."11 Unfortunately, neither of these approaches currently produces a satisfactory solution to this dilemma.

\section{A. Tithing and $\S 548$}

Courts facing the issue of tithing in bankruptcy must first consider tithing under the terms of the fraudulent conveyance statute. Section 548 of the Bankruptcy Code provides that any transfer of interest in property for which an insolvent debtor received less than a reasonably equivalent value in return is avoidable." It defines "value" as "property, or satisfaction or securing of a present or antecedent debt of the debtor." ${ }^{13}$ The case law suggests three ways to look at tithing under the statute.

The most thoroughly reasoned decision under $\$ 548$ is Christians $v$ Crystal Evangelical Free Church (In re Young). ${ }^{14}$ In that case, the Youngs had tithed for eight years and the sincerity of their religious beliefs was not at issue. In the year prior to their bankruptcy, and after they were technically insolvent, the Youngs paid a tithe of $\$ 13,450$ on work income and revenue from the sale of their house. The trustee of the Youngs' estate attempted to recover the tithe from the church as a fraudulent conveyance. The church claimed that the Youngs had received a reasonably equivalent value for their tithing by way of a tax deduction, spiritual counseling, and the opportunity to attend services in the heated, electrically lit, and air-conditioned building. ${ }^{15}$

The court held that any "property" that the Youngs received from the church was not received "in exchange" for their tithing

\footnotetext{
11 US Const, Amend I, cl 1.

1211 USC \& 548(a)(2)(A).

13 Id \$ 548(d)(2)(A).

14152 Bankr 939 (D Minn 1993).

15 Id at 948 .
} 
because they could have taken advantage of the church's services even without paying any tithe. ${ }^{16}$ According to the court, the only thing that the Youngs received in return for their tithing was the feeling that they had lived up to their religious obligations. ${ }^{17}$ The Youngs' belief that it was their religious obligation to pay the tithe did not change the fact that it was not given "in exchange" for property.

Ellenberg $v$ Chapel Hill Harvester Church, Inc. (Matter of Moses) suggests a second interpretation of how tithing should fit under $\S 548 .{ }^{18}$ In Moses, the court did not inquire whether the debtors intended to tithe only in exchange for the services provided by the church. Instead, it simply evaluated the church programs and the debtors' use of church facilities and concluded that they were equivalent in value to the $\$ 4,733.50$ that the debtors had paid in tithing during the year preceding the debtors' filing for bankruptcy. ${ }^{19}$ The court found that access to the church and the counseling that it provided constituted "property" that the debtors received in exchange for their tithing. ${ }^{20}$ In reaching this conclusion, the Moses court relied on Wilson v Upreach Ministries (In re Missionary Baptist Foundation of America, Inc.), ${ }^{21}$ an earlier case interpreting $\S 548$, for the proposition that the "property" received for a contribution need not be a tangible asset. ${ }^{22}$ The Missionary Baptist Foundation court held that the "good will" and improved employee morale that the debtor, a church organization, recieved for its charitable contributions to a nonprofit corporation constituted a reasonably equivalent value under $\S 548 .^{23}$ Along the same lines, the Moses court held that the Moseses' contributions to their church were made in exchange for the intangible, but very real, services that the church gave the debtors. ${ }^{24}$ In response to the creditors' claim that courts are constitutionally prohibited from evaluating the worth of religion and religious services, the court rather lamely noted that it was only valuing the nonspiritual services provided by the church such as marriage counseling and access to the church building. ${ }^{25}$

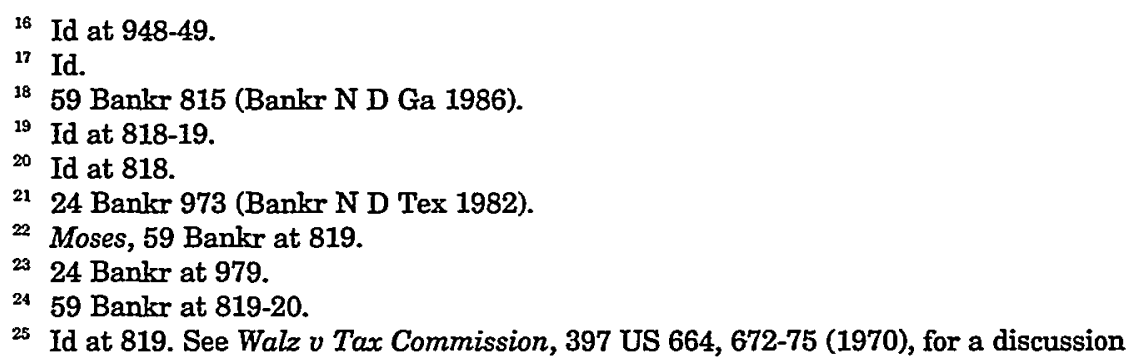


Whether the value of the church's services was equal to the value of the debtor's tithing was a moot question in Young because the court held that the Youngs' tithing was not actually exchanged for the church's services. Nevertheless, the Young court considered and rejected the argument that the Youngs received equivalent value for their tithing. It noted that the deductibility of tithing under the tax code requires that the taxpayer receive nothing in return for his or her donation, ${ }^{26}$ and that a tax deduction from gross income for tax purposes is not equivalent to having the same amount of money in cash. ${ }^{27}$ Finally; the court found the church's argument that it gave the Youngs spiritual counseling in return for their tithing unpersuasive, and stated that "emotional support . . . without more, cannot satisfy the requirement for reasonably equivalent value."28 The court did not attempt to value the Youngs' share of the utilities and other operating expenses incurred by the church over the year, but it is hard to imagine that it could have totaled $\$ 13,000$.

Furthermore, the Young court criticized Moses and Missionary Baptist Foundation for "gloss[ing] over the statutory requirements in order to reach the 'right' result." well founded. Both of these cases focused on the value of services provided without considering whether the tithes were actually given "in exchange" for those services and without giving serious consideration to the purpose of the statute. ${ }^{30}$ The Bankruptcy Code's definition of "value" as "property" is most likely an attempt to prevent debtors from defrauding creditors by claiming that they received some intangible personal satisfaction from a transfer that was a reasonable equivalent to the item transferred. ${ }^{31}$ While no "badges of fraud" are found in either Moses or

\footnotetext{
of the constitutional difficulties that arise when the government attempts to determine the value of religious practices.

${ }_{25} 152$ Bankr at 949, citing Hernandez $v$ Commissioner of Internal Revenue, 490 US 680,690 (1989), reh'g denied, 492 US 933 (1989).

${ }_{27} 152$ Bankr at 949.

${ }_{23}$ Id, citing Walker $v$ Treadwell (Matter of Treadwell), 699 F2d 1050, 1051 (11th Cir

1983) (upholding avoidance of gifts given to family members).

152 Bankr at 949 .

39 Id at 949-50.

31 The legislative history states only that:
}

Subsection (D) also defines "value" to mean property, or the satisfaction or securing of a present or antecedent debt, but does not include an unperformed promise to furnish support to the debtor or a relative of the debtor.

Bankruptcy Reform Act of 1978, S Rep No 989, 95th Cong, 2d Sess 90 (July 14, 1978), reprinted in 1978 USCCAN 5876. The House Report also contains only the passage quoted. 
Missionary Baptist Foundation, the fact remains that creditors had less money to satisfy their demands because of the debtors tithing donations. The important fact that, at least in Moses, the money was given as part of a religious exercise, is not relevant under $\S 548$ and must be addressed under the Constitution or another statute. A tithe, by its very nature, is given on faith and not for a reasonably equivalent value in worldly goods. ${ }^{32}$ Attempts to protect tithing by claiming that the debtor received value in exchange for the tithe have no basis in $\S 548$ and are, in most cases, indistinguishable from attempts to claim that gifts to friends or charities brought the debtor enough satisfaction to justify them.

A third approach to tithing under $\S 548$ is suggested by $N L R B v$ Catholic Bishop of Chicago, which requires that unless Congress clearly expressed a contrary intent, a statute must be construed to avoid constitutional difficulties whenever there is a significant risk that the First Amendment will be infringed by one of the possible constructions. ${ }^{33}$ Under this approach, because a finding that tithing is avoidable will raise concerns about the free exercise of the debtor's religion, $\S 548$ should be construed as excluding nonfraudulent religious contributions. Nothing in $\S 548$ suggests a specific congressional intent to include tithing and other religious contributions, and Congress did not specifically discuss the issue of tithing at all. ${ }^{34}$

However, in spite of Congress's failure to specifically address tithing when it debated $\S 548$, no court has interpreted the statute in this manner. In fact, the Young court specifically rejected the church's attempt to advance this argument. The court held that the bankruptcy court had correctly interpreted $\S 548$ to apply to all transfers for less than a reasonably equivalent value and that the purpose of $\S 548$ is to "maximize the size of the estate in order to maximize the distribution to innocent creditors. ${ }^{35}$ Given the language of the statute and the intent of Congress to include even transfers made in good faith, this is a reasonable interpretation. As the Young court concluded:

See Bankruptcy Reform Act of 1978, HR Rep No 595, 95th Cong, 1st Sess 375 (Sept 8, 1977), reprinted in 1978 USCCAN 6331.

32 See note 2.

33440 US 490, 504, 507 (1979).

34 See id at 504; Donald R. Price and Mark C. Rahdert, Distributing the First Fruits: Statutory and Constitutional Implications of Tithing in Bankruptcy, 26 UC Davis L Rev 853, 878-79 (1993).

${ }_{35}$ Young, 152 Bankr at 947-48. 
Strictly as a matter of statutory interpretation, there are no justifiable grounds [under $\S 548$ ] to differentiate between religious donations and other gratuitous transfers, such as gifts to family members, which are clearly avoidable. ${ }^{36}$

The terms of $\S 548$ do not distinguish between tithes and other gifts.

Given $\S 548$ 's failure to distinguish between tithes and other gifts, attempts to protect tithing under $\S 548$ are likely to be inadequate. Arguments under the rule of Catholic Bishop of Chicago are not particularly persuasive because Congress's failure to include religion specifically should not overcome its clear intent to include even transfers made in good faith. Thus, debtors and churches must turn to the Constitution or another statute to protect tithing from avoidability.

\section{B. Free Exercise Jurisprudence before Smith}

Arguments that tithing should be treated differently from other gratuitous transfers in bankruptcy are grounded in the idea that religion is somehow different from charity. The First Amendment purports to offer a special protection for the "free exercise" of religion and, for many years, so did Supreme Court interpretation of the Free Exercise Clause.

The most important decision of this "golden age" of free exercise jurisprudence was Sherbert $v$ Verner. ${ }^{37}$ In Sherbert, a Seventh Day Adventist was fired for refusing to work on Saturday, her Sabbath. Because most jobs required that she work on Saturday, she was unable to find other employment. She filed a claim for unemployment compensation, but was denied on grounds that she would not accept suitable employment (that included Saturday work) when offered. ${ }^{38}$ She sued, claiming that the agency in charge of distributing state unemployment benefits had violated her First Amendment rights.

The Supreme Court reversed the South Carolina Supreme Court's decision in favor of the agency and established a version of strict scrutiny as the prevailing standard for free exercise claims. ${ }^{39}$ Strict scrutiny was a relatively familiar standard for limiting interference with fundamental rights and had already

${ }^{36}$ Id at 949.

37374 US 398 (1963).

Is Id at $399-401$.

${ }^{2}$ Id at $403,410$. 
been used to require justification of state action in a variety of contexts. ${ }^{40}$

Sherbert's strict scrutiny standard was a two-step inquiry. The Court first considered whether the challenged regulation imposed a substantial burden on the claimant's religious belief. Then, when a substantial burden was found, the Court asked if "some compelling state interest... justifie[d] the substantial infringement of [the claimant's] First Amendment right." ${ }^{\text {41 }}$

Sherbert's test for balancing religious exercise with government interests provides significant protection to religion. In Wisconsin $v$ Yoder, the Court relied on Sherbert to invalidate a facially neutral and generally applicable statute requiring school attendance until age sixteen because it interfered with the Amish practice of removing children from school after the eighth grade to provide them with informal vocational education. ${ }^{42}$ The Court first determined that this was a religious practice rather than a philosophical choice, and then asked whether the interests of the state in compulsory school attendance for children were sufficient to override the Amish defendants' right to the free exercise of their religion. ${ }^{43}$ The Court agreed that the state's interest in compulsory education was very important but rejected the state's claim that it represented such a compelling interest that it could override the Amish's "fundamental claims of religious freedom."

Sherbert and Yoder established a rule that government regulation that infringes on religious exercise must be justified by a truly compelling governmental interest such as "the elimination of racial discrimination, national security, ... or protection from physical violence. ${ }^{.45}$ The regulation must also be the least restrictive means of accomplishing the proffered government objective. ${ }^{46}$ Infringements based only on legitimate or rational state interests and infringements that are broader than necessary are not constitutionally acceptable. The Sherbert court made this point forcefully when it stated:

\footnotetext{
40 See, for example, Thomas $v$ Collins, 323 US 516, 530 (1945) (freedom of speech); Skinner $v$ Williamson, 316 US 535, 541 (1942) (sterilization of habitual criminals); Korematsu v United States, 323 US 214, 216 (1944) (classifications based on race).

11 Sherbert, $374 \mathrm{US}$ at 406.

42406 US 205, 220-21, 234-36 (1972).

I3 at 216-21.

4 Id at 221, 234-36.

45 Price and Rahdert, 26 UC Davis L Rev at 909 (cited in note 34).

46 Yoder, 406 US at 215 (only compelling government interests "not otherwise served can overbalance legitimate claims to the free exercise of religion") (emphasis added).
} 
It is basic that no showing merely of a rational relationship to some colorable state interest would suffice; in this highly sensitive constitutional area, "[o]nly the gravest abuses, endangering paramount interests, give occasion for permissible limitation."

Under Sherbert and Yoder, only state interests of the highest order can justify infringements on the free exercise of religion.

Despite this emphatic statement regarding the importance of the Free Exercise Clause, subsequent Court decisions eroded the high standard of protection for religious exercise established in Sherbert. The Court became more deferential to legislative infringements on religious exercise, and the "strict scrutiny" standard of Sherbert became, in many cases, a paper tiger. ${ }^{48}$ In these cases, the strict scrutiny standard became highly contextual and not nearly as determinative of outcomes as in other areas of constitutional law. The Court frequently allowed the government to prevail so long as the regulation of religious conduct was solidly based on legitimate secular ends.

The Court came to rest at the bottom of its slippery slope in Employment Division, Oregon Department of Human Resources $v$ Smith. ${ }^{49}$ Smith involved two members of the Native American Church who were fired by a drug rehabilitation organization and denied unemployment benefits because of their sacramental use of peyote in violation of Oregon's general ban on peyote use. Rather than determining whether the state had a compelling

47374 US at 406, quoting Thomas, 323 US at 530.

43 For a discussion of judicial manipulation of the Sherbert test, see Comment, Toward a Fuller Understanding of Religious Liberty: Recognizing the Identity-Generative and Expressive Nature of Religious Devotion, 62 U Chi L Rev 1241 (1995). See also Price and Rahdert, 26 UC Davis L Rev at 890-91 (cited in note 34):

Far from being "strict in theory and fatal in fact," as the compelling interest standard has sometimes been in other spheres, this standard has produced more instances in which the Court upheld state regulation of religious practices than cases in which the Court struck down such regulations.

Price and Rahdert cite as examples Jimmy Swaggart Ministries $v$ Board of Equalization, 493 US 378 (1990) (imposition of sales and use tax on distribution of religious materials); Hernandez $v$ Commissioner of Internal Revenue, 490 US 680 (1989), reh'g denied, 492 US 933 (1989) (denial of tax deduction for religious payment); Bowen $v$ Roy, 476 US 693 (1986) (plurality opinion) (requirement of use of Social Security number against sincere religious objections); Goldman $v$ Weinberger, 475 US 503 (1986) (prohibition of Orthodox Jew from wearing yarmulke during military duty); Gillette $v$ United States, 401 US 437 (1971) (requirement of military conscription of persons religiously opposed to particular wars, as opposed to all wars). Price and Rahdert, 26 UC Davis L Rev at 891 n 161 (cited in note 34$)$.

${ }^{19} 494$ US 872 (1990). 
interest in banning even the sacramental use of peyote, the Court departed from the language of Sherbert and Yoder and declared that any law that is both neutral on its face and generally applicable does not violate the First Amendment even if it places a substantial burden on religion. ${ }^{50}$

Smith was the culmination of decades of precedent weakening the strict scrutiny standard established in Sherbert. Its holding is in direct conflict with Yoder and Sherbert ${ }^{51}$ and has led some commentators to wonder whether, in cases to which Smith applies, the Free Exercise Clause offers any protection for religion that is not available under the Equal Protection Clause of the Fourteenth Amendment. ${ }^{22}$ Under Smith, the Free Exercise Clause seems to guarantee only that members of a religious minority will be treated the same as everyone else, even if the religion's doctrine requires its members to behave differently. ${ }^{53}$ In effect, Smith guarantees that religion receives no more respect than philosophical or lifestyle choices of much lesser importance.

\section{Tithing and the Constitution after Smith}

If a party demonstrates that its case, like Sherbert and the other unemployment benefits cases, falls under a statute that is made to deal differently with individual cases, the rule in Smith will not apply and the court will evaluate the challenged government action under the compelling interest test. The Smith Court stated that, "where the State has in place a system of individual exemptions, it may not refuse to extend that system to cases of 'religious hardship' without compelling reason.. ${ }^{\text {.54 }}$

The Bankruptcy Code as a whole is an excellent example of a law designed to be tailored to fit individual cases, and, as a result, decisions concerning the Code may fall outside the rule of Smith. ${ }^{55}$ There are numerous exemptions in the Code for every-

so Id at, 878-82.

51 Contrast Yoder, 406 US at 220, and Sherbert, 374 US at 402-03, 406-09, with Smith, 494 US at 882-89.

52 See Douglas Laycock, Free Exercise and the Religious Freedom Restoration Act, 62 Fordham L Rev 883, 903 (1994). See also Michael W. McConnell, Accommodation of Religion: An Update and a Response to the Critics, 60 Geo Wash L Rev 685, 691 (1992) (noting that a view of the Free Exercise and Establishment Clauses of the First Amendment as nothing more than specialized equal protection clauses makes them violate themselves by singling out religion for special protection).

53 For example, under Smith, a Jehovah's Witness or a Quaker could be drafted and required to be an infantry soldier just as a nonreligious draftee.

54494 US at 884, citing Bowen $v$ Roy, 476 US 693, 708 (1986).

${ }^{55}$ See Comment, To Tithe or Not to Tithe: The Constitutionality of Tithing in Chapter 
thing from life insurance policies and business tools to stereo equipment and television sets; consequently, the entire process of reorganization or liquidation is one of fitting broad policies to individual needs. ${ }^{56}$ The highly individualized results of bankruptcy proceedings contrast sharply with Smith's requirement of uniform treatment.

The Supreme Court's decision in Church of the Lukumi Babalu Aye, Inc. $v$ City of Hialeah ${ }^{57}$ underscores the fact that statutes which have many exceptions or are not uniform in application do not come within the rule of Smith. In Church of the Lukumi Babalu Aye, a series of ordinances that prohibited the killing of animals purported to be generally applicable but was, in practice, riddled with exceptions for virtually everything other than the ritual killings performed by Santeria churches. The Court, viewing the ordinances as a single legislative act, declared them all unconstitutional. ${ }^{58}$

Section 548 is very similar to the facially neutral ordinance found unconstitutional in Church of the Lukumi Babalu Aye. It is, by itself, facially neutral and generally applicable, but it is part of a system of individualized exemptions that results in the very type of individually tailored outcomes that the Smith Court said still require a compelling interest/least restrictive means analysis.

Although there is merit to the argument that the Bankruptcy Code is a system of individualized exemptions outside the scope of Smith, courts have sidestepped it by focusing on individual provisions rather than the entire Bankruptcy Code when deciding cases involving religion. All four of the courts that decided cases after Smith have declined to look at the "individualized system" of the Bankruptcy Code and have, instead, looked narrowly at the specific provisions and found that they are facially neutral and generally applicable. ${ }^{59}$ The language of $\S 548$ allows all

13 Bankruptcy Budget, 32 Santa Clara L Rev 1231, 1249-50, 1257-58 (1992) (arguing that Chapter 13 bankruptcy plans are exactly the kind of individualized law that fits under Sherbert rather than Smith).

¿6 See Amici Curiae Brief for Christian Legal Society, et al, at 6, In re Young, No CIV 4-93-76 (8th Cir 1993) (on file with U Chi L Rev).

st 113 S Ct 2217 (1993).

\&s Id at 2227-29.

59 See Young, 152 Bankr at 952-53; In re Faulkner, 165 Bankr 644, 648 (Bankr W D Mo 1994) (Section 707(b) of the Code is facially neutral and generally applicable under the rule of Smith.); In re Lee, 162 Bankr 31, 42 (Bankr N D Ga 1993) (same); In re Lynn, 168 Bankr 693, 700 (Bankr D Ariz 1994) (Section 523(a) is facially neutral and generally applicable.). None of these cases examines the broader "system of individualized exemptions" 
transfers that meet its criteria to be avoided, regardless of the intent of the debtor or the other party to the transaction. The burden it places on religion is substantial, but it is clearly incidental to the broader policy behind the rule.

A second distinction between bankruptcy proceedings challenging tithing payments and the Smith decision is that tithing cases involve "hybrid claims" that affect freedom of speech and association as well as religious freedom. This argument is based on Smith's suggestion that even facially neutral and generally applicable statutes will be required to pass the compelling interest test if, in addition to the Free Exercise Clause, they burden other constitutional rights as well. ${ }^{60}$ The payment of tithes is speech to the extent that financial contributions demonstrate support for the policies of a particular church. ${ }^{61}$ Tithing also implicates the freedom of association because, by making tithing avoidable under $\S 548$, the government may be limiting the ability of debtors to associate with others who attend their church. This argument is most effective where privileges of membership depend on the payment of tithes.

The strength of the "hybrid claims" argument is questionable. The Washington Supreme Court, in Fi,st Covenant Church of Seattle $v$ City of Seattle, relied on this exception to Smith when it struck down a Seattle landmark ordinance. ${ }^{62}$ However, the First Covenant Church decision was also based on the "individualized exemption" exception ${ }^{63}$ noted above, and at least one commentator has suggested that the only reason that the Smith Court created the "hybrid claims" category at all was to distinguish disfavored precedent. ${ }^{64}$ In addition, Justice Souter, in Church of the Lukumi Babalu Aye, has questioned whether the "hybrid" exception to Smith rests on any genuinely principled basis at all. ${ }^{65}$

In spite of these arguments, the case for treating tithing as a fraudulent conveyance after Smith remains strong. The Young court's focus on the specific provision rather than the Bankruptcy

\footnotetext{
that makes up the Bankruptcy Code.

so See Smith, 494 US at 881-82.

61 See, for example, Buckley v Valeo, 429 US 1, 20-21 (1976) (recognizing financial contributions to political candidates as expression); Riley $v$ Natl. Federation for the Blind of North Carolina, Inc., 487 US 781, $787-88$ (1988) (finding solicitation of charitable contributions to be protected speech).

62 120 Wash 2d 203, 840 P2d 174, 181-83 (1992).

63 Id at 180-81.

64 See McConnell, 60 Geo Wash L Rev at 696 (cited in note 52).

65 $113 \mathrm{~S} \mathrm{Ct}$ at 2244-45 (Souter concurring in part and concurring in the judgment).
} 
Code as a whole is reasonable even though a broader view of the governing statute would better protect religious liberty. In fact, the Young court's holding on this issue has already been followed by courts addressing other areas of bankruptcy law. ${ }^{66}$

The case for protecting tithing from creditors of a Chapter 7 debtor under the Free Exercise Clause remains plausible after Smith, but, since courts have generally decided differently, ${ }^{67}$ debtors face an uphill battle. Neither the "individualized exemption" nor the "hybrid claim" exceptions to Smith, as currently construed, provides the basis for heightened scrutiny of tithing avoidance under $\S 548$. As a result, RFRA is particularly important to debtors who tithe.

\section{RFRA-Congress's Response to Smith}

RFRA is, essentially, a legislative veto of the Supreme Court's decision in Smith. It had a broad base of support and moved quickly through the legislative process. RFRA was introduced to the Senate in May of 1993, approved by an almost unanimous vote in both houses, ${ }^{68}$ and signed into law in November of the same year. ${ }^{69}$ Its explicitly stated purpose is:

[T]o restore the compelling interest test as set forth in Sherbert $v$. Verner... and Wisconsin v. Yoder... and to guarantee its application in all cases where free exercise of religion is substantially burdened. ${ }^{70}$

Congress's direct and virtually unanimous rejection of the Supreme Court's decision in Smith sent the clear message that Smith was an inappropriate means of evaluating free exercise claims.

The requirements of RFRA are simple. Someone wishing to invoke the protection of the Act must show that the government is placing a "substantial burden" on the free exercise of her religion. Once she has done this, the government must demonstrate

65 See, for example, Faulkner, 165 Bankr at 648; Lynn, 168 Bankr at 698.

67 See cases cited in note 59.

68 RFRA passed ninety-seven to three in the Senate and was passed by a voice vote in the House of Representatives. See 139 Cong Rec S14471 (Oct 27, 1993); 139 Cong Rec H2363 (May 11, 1993).

69 Religious Freedom Restoration Act, S Rep No 103-111, 103d Cong, 1st Sess (1993), reprinted in 1993 USCCAN 1892.

${ }^{70} 42$ USC $\S 2000 \mathrm{bb}(\mathrm{b})(1)$. The Act also enumerated a second purpose: “[T]o provide a claim or defense to persons whose religious exercise is substantially burdened by government." Id § $2000 \mathrm{bb}(\mathrm{b})(2)$. 
that its actions are "in furtherance of a compelling governmental interest" and that the challenged government action is the "least restrictive means of furthering that compelling government interest." ${ }^{71}$ This language attempts to return free exercise claims to the standard enunciated in Sherbert. As a result, free exercise claims must now be considered under the compelling interest test. $^{72}$

\section{TIthing AND THE COMPELling INTEREST TEST}

The passage of RFRA provides a great deal of comfort to religions that tithe because they no longer have to wonder whether courts will examine tithing in bankruptcy cases under Smith's rule or under Sherbert's compelling interest test. Under RFRA, the relevant questions are whether avoiding tithing as a fraudulent conveyance imposes a substantial burden on religion and, if it does, whether the government's interest in avoiding these tithing payments is sufficiently compelling. This Section argues that allowing creditors to undo tithing payments made up to a year before bankruptcy imposes a substantial burden on religions that tithe and is not justified by any compelling government interest.

A. Section 548 Is a Substantial Burden on the Exercise of Religion

Whether interference with a religion's requirement that its members pay tithes is a substantial burden is not a difficult question in most cases. Many religions teach that tithing is a commandment from God-some even require that church members assert to church officials that they are paying a full tithe if they wish to participate in certain ordinances or church activities. ${ }^{73}$ Allowing creditors to avoid tithing payments as fraudulent conveyances forces members of these religions to choose

71 Id $\S 2000 \mathrm{bb}-1(\mathrm{a})(2)$

72 See, for example, Amicus Curiae Brief for Senator Orrin G. Hatch at 5-7, In re Young, No CIV 4-93-76 (8th Cir 1995) (on file with U Chi L Rev). See also Campos $v$ Cougalia, 854 F Supp 194, 204-07 (S D NY 1994) (ruling, on motion for preliminary injunction, that under RFRA's compelling interest standard, inmates established likelihood of success on the merits where prison officials confiscated sacramental beads).

${ }_{73}$ For example, the Church of Jesus Christ of Latter Day Saints requires that all members who attend its temples be full tithe payers. See also Moses, 59 Bankr at 816 (debtor required to pay tithing to participate in his role as a deacon of the church). 
between their religious belief in tithing and the protection of the bankruptcy courts. ${ }^{74}$

The price of bankruptcy code protection for these debtors is very high. They must stiff God in order to satisfy their other creditors. This is a tough choice to make, even in the face of serious financial difficulty. God has promised enormous blessings to those who tithe and harshly condemns those who do not. $\mathrm{He}$ has said "[w]ill a man rob god? Yet ye have robbed me. But ye say, Wherein have we robbed thee? in tithes and offerings. Ye are cursed with a curse: for ye have robbed me, even this whole nation. ${ }^{375}$ If tithing is avoidable as a fraudulent conveyance, tithepaying debtors who file for bankruptcy protection are required to "rob God" and invoke a curse on their own heads in order to obtain the protection of the Bankruptcy Code. This is quite a price.

It is hard to feel too sorry for irresponsible debtors who have spent more money than they have and have arguably brought this "curse" upon themselves, but many debtors do not fit this profile. The fact also remains that $\S 548$ exacts a much higher price from a debtor who tithes than from a debtor who does not. Tithe-paying debtors must essentially choose between this world and the next by violating sacred commandments to obtain Bankruptcy Code protection. Their counterparts who do not tithe sacrifice nothing to receive the same protection.

The burden that $\S 548$ places on religious exercise is made more oppressive by the Bankmiptcy Code's liberal definition of insolvency. The Code states that a person or entity is insolvent whenever the sum of the person's or entity's debt is greater than the sum of his or its property, at a fair valuation. ${ }^{76}$ This means that virtually everyone who has student loans, credit card debt, or a car bought on credit is likely to be insolvent. Under this definition, a large percentage of Americans who never go into bankruptcy are continually "insolvent" under the Bankruptcy Code.

Such a sweeping definition of insolvency is significant because, even if a debtor's bankruptcy is due to a sudden financial shock rather than a long, drawn out process of willfully failing to

74 By allowing tithing to be recovered by creditors, the protention offered by the Bankruptcy Code requires outright rejection of the belief that God should io a "preferred creditor" and should be paid before all other creditors.

75 Malachi 3:8.

${ }^{26} 11$ USC $\S 101(32)(A)(1988)$. 
meet financial obligations or an attempt to defraud creditors, the creditors can still avoid tithing transactions made up to a full year earlier. These donations will often have occurred long before anyone, even the creditors, could have reasonably objected to them. As a result, religions and sincere tithe payers will be forced to wait an entire year from payment before knowing if tithing obligations have been met. Thus, while $\S 548$ is a good rule for preventing fraud, it is inappropriate in the context of tithing and clearly places a substantial burden on the religious freedom of people who desire to tithe. ${ }^{77}$

These are compelling arguments that $\S 548$ imposes a substantial burden on individuals who tithe. In contrast, creditor arguments that tithes paid while a person is insolvent are paid with other people's money and that allowing creditors to collect tithes paid while the payer was insolvent will only have a very small effect on church finances are unconvincing.

The argument that avoiding tithing payments imposes no religious burden on a debtor because the payments were made with other people's money is unsupported by bankruptcy law, the common law view of personal contracts, or RFRA. Unsecured creditors have no property rights in any specific property of debtors, ${ }^{78}$ and debtors are free to spend money as they please before they enter into bankruptcy proceedings. In fact, so long as the evidence does not show an "intent to hinder, delay or defraud a creditor, ${ }^{, 79}$ debtors can, within one year of filing, spend money on extravagant personal consumption, ${ }^{80}$ investments in exempt property, ${ }^{81}$ investments pursuant to fraudulent business

77 Government interference with church organizations' finances also raises Establishment Clause concerns under the First Amendment. These concerns are not relevant to the substantial burden inquiry except as noted in the text accompanying this note. In any event, these arguments are not compelling in the case of $\S 548$. Section 548 was challenged in Young as an example of excessive government entanglement with religion because it allows government to reach directly into a church's offering plate to recover tithing money. See Young, 152 Bankr at 955 . The court rejected this argument because the enforcement of $\$ \mathbf{5 4 8}$ involves no inquiry into religious doctrine. Id.

${ }_{78}$ See Louisville Joint Stock Land Bank $v$ Radford, 295 US 555, 588 (1935).

79 See 11 USC \& 548.

8o See, for example, In re Wegner, 91 Bankr 854, 858-60 (Bankr D Minn 1988) (debtor with $\$ 100,000$ in credit card debt and living expenses in excess of income granted Chapter 7 discharge). The Wegner court stated:

There is no question that this case arises from the debtors' financial irresponsibility. However, were the courts to dismiss every Chapter 7 case filed by a financially irresponsible debtor, Chapter 7 as a form of relief would soon be extinct.

Id at 860 .

81 See In re Armstrong, 931 F2d 1233, 1237-38 (8th Cir 1991) (stating that transfer- 
schemes ${ }^{82}$, and gambling, ${ }^{83}$ without having the transactions avoided. In most cases, there is no repercussion for this spending because the money belonged to the debtor when she spent it. In extreme cases of irresponsibility or fraudulent intent, this spending may provide an argument for refusing to discharge the debtor, but it is never avoidable as a fraudulent transfer because unsecured creditors have a personal guarantee of payment. ${ }^{84}$ They have no property interest in any of the property of the debtor. The debtor's property remains her own to do with as she pleases until she seeks protection from her creditors under the Bankruptcy Code.

Creditors might also argue that the avoidability of tithing in bankruptcy proceedings will only interfere with a few payments. As a result, it will not have a significant impact on church finances and does not constitute a substantial burden. However, this argument ignores the importance of even one person's tithing to a church that is struggling financially and inappropriately shifts the focus from the individual to the institution. These are serious oversights because even if churches as a whole are forced to return only a small number of their tithing payments, the religious implications for the tithing member and the financial impact on those churches that are placed in the situation of returning large sums of tithing could be significant. Further, this argument is easily flipped to justify a position of protecting tithing payments. If the overall amount of tithing at issue truly is insignificant, then there is really no justification for the intrusion into church affairs that the creditors' view of $\S 548$ would allow.

In sum, allowing creditors and bankruptcy trustees to avoid tithing payments under $\S 548$ imposes a substantial burden on the exercise of religions that tithe. Tithe-paying debtors believe that tithing is the Law of God. A policy of avoiding tithing pay-

ring property into exempt forms does not, by itself, evidence intent to defraud); In re Johnson, 880 F2d 78, 83-84 (8th Cir 1989) (same); Norwest Bank Nebraska, N.A. v Tveten, 848 F2d 871, 873-74 (8th Cir 1988) (same). But see In re Davidson, 164 Bankr 782, 785 (Bankr S D Fla 1994) (stating that transfers into exempt forms to prevent access by creditors, even if accompanied by other motives, is sufficient to find fraud); In re Piontek, 113 Bankr 17, 21-22 (Bankr D Or 1990) (noting disagreement among courts on this issue).

E2 See In re Universal Clearing House Co., 60 Bankr 985, 997-1000 (D Utah 1986) (preserving transfer for services made in furtherance of fraudulent business scheme when services were of reasonably equivalent value).

\&3 See Daniel R. Cowans, 1 Bankruptcy Law \& Practice \$ 5.43 at 741-42 (West, 6th ed 1994) (noting that losing money at gambling must be corroborated, but that the debtor will receive a discharge once evidence shows that she actually did lose the money).

Bs Third parties who exchange goods with a reasonably equivalent value to the money they receive are not governed by $\S 548$. 
ments essentially forces these debtors to choose between the protection of the Bankruptcy Code and the Will of God. Creditor arguments that the tithing payment was really made with creditors' money and that avoiding tithing would only result in a small number of avoided claims are unsupported by the law, inappropriately attempt to shift the focus from the debtor's religious exercise to the church's financing, and, even then, ignore the importance of even a small amount of tithing to a struggling church.

\section{B. Compelling Interests Test}

Where there is no question as to the debtor's sincerity and no question of fraud arises, the only interest that the government can assert to justify this burden on religious exercise is its interest in increasing the resources available to creditors. This alone, however, is clearly not a compelling interest.

Under the compelling interest test, governmental regulation that infringes on religious exercise must be justified by a truly compelling government interest such as national security, the elimination of racial discrimination, or protection from physical violence. ${ }^{85}$ As the Sherbert Court noted, "only the gravest abuses, endangering paramount interests, give occasion for permissible limitation." ${ }^{86}$ Tithing paid with a sincere heart and no intent to defraud creditors can hardly be thought of as a "grave abuse" of religious freedom. Likewise, protecting the marginal interests of creditors cannot seriously be considered a state interest equal in importance to national security, ending racial discrimination, or preventing physical violence.

In fact, the only significant interest here is the interest of creditors in recovering a few more dollars, and this is far from a compelling national interest. ${ }^{87}$ The Bankruptcy Code itself is

85 Price and Rahdert, 26 UC Davis L Rev at 909 (cited in note 34).

${ }^{86} 374$ US at 406, quoting Thomas $v$ Collins, 323 US 516, 530 (1945).

${ }^{87}$ But see Young, 152 Bankr at 954 (stating in dicta and without considering the breadth of $\S 548$ that "[t]he government's policy of allowing debtors to get a fresh start while at the same time treating creditors as fairly as possible qualifies as a compelling interest"). Note that this policy is the policy of the Bankruptcy Code as a whole, not the policy of $\S 548$. Essentially, the Young court is trying to have it both ways by focusing narrowly on $\S 548$ when deciding the neutrality and general applicability issues, but allowing the government to assert the broad policies of the entire Bankruptcy Code when considering the compelling interest test. See id. As Justice Blackmun noted in his dissent in Smith, both of these inquiries must be made at the same level of generality for the inquiry to have any meaning at all. 494 US at 910-11. See also J. Morris Clark, Guidelines for the Free Exercise Clause, 83 Harv L Rev 327, 330-31 (1969) ("The purpose of 
riddled with exemptions that subordinate creditors' marginal interests to those of the debtor in many areas. Examples of this subordination of creditor interests include exemptions for the debtor's equity interest in a home (up to $\$ 15,000$ ); ${ }^{88}$ an automobile (up to $\$ 2,400$ ); ${ }^{89}$ other business tools, machines, or instruments (up to $\$ 1,500) ;{ }^{90}$ clothing, furniture, and appliances, including stereos and televisions (up to an aggregate of $\$ 8,000$ ); $;^{91}$ and numerous other expenditures. ${ }^{92}$ The Code also allows debtors to elect to take the exemptions allowed under state law, which are often even more generous. ${ }^{93}$ Obviously, the government's interest in increasing the resources available to creditors is not "compelling" or of "paramount" importance in these situations because the Bankruptcy Code itself allows the debtor's interests in keeping these items to override the government's interest in collecting more money for creditors. One advocate in the Young appeal noted the absurdity of arguing that "there exists a governmental interest compelling enough to override a debtor's good faith exercise of his religious obligations, but not so compelling as to invalidate his purchase of a tractor, a new car, a television, or a refrigerator. ${ }^{94}$ This type of absurdity was flatly rejected by the Supreme Court's decision in Church of Lukumi Babalu Aye, which requires that a governmental interest cannot qualify as "compelling" if the government does not treat the interest as compelling "in all contexts in which it arises."

In sum, the compelling interest standard of Sherbert and RFRA requires a pressing national interest on a much higher level than the government is able to offer here. Increasing the pool of funds available to creditors does not qualify as an interest

almost any law can be traced back to one or another of the fundamental concerns of government . . . ."); Roscoe Pound, A Survey of Social Interests, 57 Harv L Rev 1, 2 (1943) ("When it comes to weighing or valuing claims or demands with respect to other claims or demands, we must be careful to compare them on the same plane. . . [Or else] we may decide the question in advance in our very way of putting it.").

8811 USC \& 522(d)(1) (1988).

$\therefore$ Id $\S 522(d)(2)(1988)$.

so Id $\S 522(d)(6)(1988)$.

91 Id $\S 522(d)(3)(1988)$.

s2 See id $\$ 522(d)$ (1988).

93 Id $\$ 522(\mathrm{~b})(2)(\mathrm{A})$. For example, in California the exemption for a home is $\$ 50,000$, $\$ 75,000$, or $\$ 100,000$, depending on the debtor's circumstances. See Cal Civ Proc Code $\$$ 704.730(a) (West 1987 \& Supp 1995).

94 See Amicus Curiae Brief for Senator Hatch at 7, Young, No CIV 4-93-76 (cited in note 72).

95 See Church of Lukumi Babalu Aye, $113 \mathrm{~S} \mathrm{Ct}$ at 2234. See also Amicus Curiae Brief for Senator Hatch at 7-8, Young, No CIV 4-93-76 (cited in note 72). 
so compelling that the government can justify reaching into the coffers of a church to recover tithing payments made with a sincere belief that God requires them.

Under RFRA, if protecting the marginal interests of creditors is somehow found to be a compelling interest in spite of the arguments above, the government must also show that avoiding tithing payments is the least restrictive means of accomplishing this objective. This argument poses less of a barrier for the government. In the case of $\S 548$, there are no collateral effects that make it overbroad because all $\S 548$ does is authorize recovery of money that will increase the pool of funds available to creditors. As a result, the government would not have any problem fulfilling the second requirement of the RFRA test.

A second and even less tenable position that the government could take is that the "compelling" interest protected here is really fraud on creditors. However, the sincerity of the giver is generally not in question in tithing cases, and a brief inquiry into past practices of the debtor will easily avoid any question of fraud. If a debtor has tithed for several years, she is almost certainly not trying to defraud her creditors. If, however, the debtor has never tithed and then makes a large one-time payment to her church on the eve of bankruptcy, the sincerity of her actions will be easy to question. Even in the unlikely event that creditors could convince courts that the real issue underlying $\S 548$ is fraud, avoiding all tithing transfers under $\S 548$ is clearly not the least restrictive means of accomplishing that objective. By looking at past practices of the debtor, it is relatively easy to distinguish between fraudulent and honest tithes.

Under the compelling interest/least restrictive means rule required by RFRA, the case for protecting churches and tithe payers from bankruptcy trustees and creditors is very strong. The debtor has an indisputable property interest in the money that she is tithing, and pays in an attempt to obey God's commandment. To nullify her religious exercise of tithing is without doubt a substantial burden on her religion and ignores the exercise of faith that inevitably accompanies the transfer of such a significant amount of one's money without consideration. The only governmental interests that could justify such a burden are those of the highest order and of paramount importance. Making the pool of money available to creditors marginally bigger is clearly not such an interest; it is definitely not of the order that justifies 
an infringement on the free exercise of religion, one of the fundamental liberties of our great nation. ${ }^{96}$

\section{CONCLUSION}

Tithing is a sacred obligation that many religious people take very seriously. Fraudulent conveyance law is also very important to the proper functioning of a bankruptcy system, and the intersection of these two laws often results in a collision of values. The act of balancing the interests of creditors with the religious. exercise of debtors is very important, and, until recently, even the standard that should be used to evaluate the conflict between fraudulent conveyance law and tithing was uncertain.

Congress was unwilling to wait and see whether Smith would move free exercise jurisprudence into a new era or whether its exceptions would be expanded to make it only a benchmark in the development of constitutional law. The passage of RFRA was intended to dispel doubts about the continued vitality of religious freedom in America. This Comment views RFRA as an important success for religious contributors because it removes any doubt that the appropriate standard for evaluating tithing is the compelling interest/least restrictive means rule of Sherbert.

Since the passage of RFRA, the argument for protecting tithing from avoidance has become very strong. Creditors can only assert that the burden of avoiding tithing payments is not substantial because the tithing was paid with money already owed to someone else and that somehow creditors' marginal recoveries are a compelling interest justifying interference with the religious exercise of tithe payers. These arguments are simply too weak to pose a serious threat to tithing. The more important question now is whether courts will protect tithing under the "individualized exemption" exception to Smith or under the newly available RFRA provisions.

The answer to this question is not easy because it is not clear that these two roads will lead to different places. Both rules require a court to apply Sherbert's compelling interest test and both will likely result in protection for tithing paid with a sincere heart. Decisions under either RFRA or the Constitution will protect tithing from overreaching creditors without protecting money that was not paid as part of a sincere religious exercise.

96 See Yoder, 406 US at 214. 
This is an appropriate balance between the Law of tithing and the law of fraudulent conveyances. 